\title{
EFFECTS OF ARBUSCULAR MYCORRHIZAL FUNGI AND PHOSPHORUS FERTILIZATION ON POST VITRO GROWTH OF MICROPROPAGATED Zingiber officinale $\operatorname{ROSCOE}^{(1)}$
}

\author{
Rosilda dos Santos ${ }^{(2)}$, Carla Giovana Girardi ${ }^{(3)}$, Rosete Pescador $^{(4)} \&$ \\ Sidney Luiz Stürmer ${ }^{(5)}$
}

\begin{abstract}
SUMMARY
The rhizomes of Zingiber officinale Roscoe (ginger) are widely used for their medicinal and flavoring properties, whereas the influence of root symbionts on their growth is poorly understood. In this study, the effects of phosphate fertilization and inoculation with a mixture of arbuscular mycorrhizal fungi (AMF) (isolates Glomus clarum RGS101A, Entrophospora colombiana SCT115A and Acaulospora koskei SPL102A) on survival, growth and development of micropropagated ginger were investigated. After transplanting to post vitro conditions, the ginger microplants were subjected to the following treatments: a) AMF mixture, b) P addition (25 mg kg-1), c) AMF + P, and d) non-mycorrhizal control without $P$ addition. After eight months of growth, survival ranged from 86 to $100 \%$ in the $\mathrm{AMF}$ and $\mathrm{AMF}+\mathrm{P}$ treatments versus $71 \%$ survival in control and $\mathrm{P}$ treatments. In the AMF, $\mathrm{P}$ and $\mathrm{AMF}+\mathrm{P}$ treatments, the shoot, root and rhizome biomass production were significantly larger than in the control plants. In the nonmycorrhizal control plants the leaf number, leaf area, number of shoots/plants, and shoot length were significantly lower than in the AMF, P and AMF+P treatments. Root colonization ranged from 81 to $93 \%$ and was not affected by $P$ application. The data confirmed the response of several growth variables of micropropagated ginger to mycorrhizal colonization and $\mathrm{P}$ addition.
\end{abstract}

Index terms: Acclimatization, root colonization, fungal communities

\footnotetext{
(1) Received for publication in June 2009 and approved in February 2010.

(2) Graduate student of the Master Program Teaching of Natural Sciences and Mathematics - FURB. E-mail: sida_formento@yahoo.com.br

(3) Graduate student of the Master Program in Environmental Engineering - FURB. E-mail: carlaggirardi@gmail.com

(4) Professor of Departamento de Fitotecnia, Universidade Federal de Santa Catarina - UFSC. Rod. Admar Gonzaga, Km 3 , B. Itacorubi. CEP 88034-001 Florianópolis (SC) Brazil. E-mail: rosete@cca.ufsc.br

(5) Professor of Departamento de Ciências Naturais, Universidade Regional de Blumenau - FURB. R. Antonio da Veiga, 140. Cx. P. 1507. CEP 89012-900 Blumenau (SC) Brazil. E-mail: sturmer@furb.br
} 


\title{
RESUMO: EFEITOS DOS FUNGOS MICORRÍZICOS ARBUSCULARES E FERTILIZAÇÃO FOSFATADA NO CRESCIMENTO POST VITRO DE Zingiber officinale ROSCOE MICROPROPAGADOS
}

\begin{abstract}
Rizomas de Zingiber officinale Roscoe (gengibre) são amplamente utilizados em razão do seu potencial medicinal e culinário, no entanto a influência de simbiontes radiculares no seu crescimento é pouco conhecida. Neste estudo, foram investigados os efeitos da fertilização fosfatada e da inoculação com uma mistura de fungos micorrizicos arbusculares (FMAs) (isolados Glomus clarum RGS101A, Entrophospora colombiana SCT115A e Acaulospora koskei SPL102A) na sobrevivência, crescimento e desenvolvimento de gengibre micropropagado. No transplante para as condições de post vitro, microplântulas de gengibre foram submetidas aos seguintes tratamentos: mistura de FMAs; adição de P (25 mg $\left.\mathrm{kg}^{-1}\right) ; F M A s+P$; e controle não micorrízico sem adição de P. Após oito meses de crescimento, a sobrevivência variou de 86 a $100 \%$ nos tratamentos FMAs e FMAs+P contrastando com $71 \%$ nos tratamentos com adição de $P$ e controle. Os tratamentos FMAs, $P$ e FMAs $+P$ resultaram na produção significativamente maior de biomassa da parte aérea, raízes e rizomas do que as plantas controle. Plantas controle não-micorrizadas tiveram significativamente menor número de folhas, área foliar, número de brotos por planta e comprimento da parte aérea do que os tratamentos FMAs, P e FMAs+P. A colonização radicular variou de 81 a $93 \%$ e não foi alterada pela adição de $P$. Os dados obtidos confirmam a resposta de diferentes variáveis de crescimento de gengibre micropropagado à colonização micorrízica e adição de fósforo.
\end{abstract}

Termos de indexação: aclimatização, comunidades fúngicas, colonização radicular.

\section{INTRODUCTION}

Arbuscular mycorrhizal fungi (AMF) are natural inhabitants of soil that establish the mutualistic arbuscular-endomycorrhizal symbiosis with $c a .80 \%$ of the terrestrial flowering plants (Smith \& Read, 1997). AMF are obligatory symbionts and therefore rely solely on their plant partner to obtain carbohydrates used for intra and extra-radical vegetative growth and sporulation. On the other hand, the extra-radical mycelia of AMF grow into the bulk soil and scavenge for immobile mineral nutrients that are translocated back to the host plant. Consequently, the fungal partner contributes significantly to the mineral nutrition of the host plant, especially in terms of P uptake (Smith \& Read, 1997). In addition to plant growth and mineral nutrition, AMF enhance plant resistance to biotic (e.g. plant pathogens) and abiotic (e.g. drought) stresses (Newsham et al., 1995; Dodd, 2000) and provide important ecosystem services by contributing to soil aggregation (Purin \& Rillig, 2007).

Micropropagation is a successful technique for rapid plant propagation and can be used to obtain highquality, disease-free and homogenous plants of economically important horticulture crops, fruit trees and woody species (Taylor \& Harrier, 2000). During the micropropagation cycle, the absence of beneficial microorganisms during the early stages of post vitro acclimatization can adversely affect survival, growth and nutrition of in vitro-grown plantlets (Fortuna et al., 1996; Borkowska, 2002). This is particularly important for mycorrhizal-dependent (Monticelli et al.,
2000), micropropagated species that are transplanted to a sterile substrate. AMF inoculation in the post vitro phase enhanced growth and nutrition of apple and plum rootstocks (Fortuna et al., 1996; Locatelli et al., 2002; Cavallazzi et al., 2007), modified root morphogenesis and influenced nutrient uptake in grapevine (Schellenbaum et al., 1991), contributed to protection against phytopathogens in pineapple (Guillemin et al., 1994), and increased strawberry yield (Sharma \& Adholeya, 2004). To our knowledge, the effect of AMF on the growth of micropropagated ginger has not been evaluated so far.

In Brazil, ginger Zingiber officinale Roscoe (Zingiberaceae) is cultivated mainly in the state of Paraná, in the municipality of Morretes, with an annual production of about 4,260 $t$ (Epagri, 1998). In the state of Santa Catarina, ginger was first planted in 1994 in the Itajai Valley and came to be an alternative crop for small and medium growers. Ginger production is mainly based on family farms; $70 \%$ of the production is exported to England, USA, Canada, Netherlands, Germany, and the Arab Emirates (Epagri, 1998). A major problem of ginger growers is the production of seedlings with poor sanitary quality since "seed pieces" cut out from mature rhizomes are used to replant crops. This practice, however, is probably responsible for the increase of diseases with each new growth cycle caused by Fusarium oxysporum, root-knot nematodes (Meloidogyne spp.) and soft rot bacteria (Erwinia carotovora) (Epagri, 1998).

The production of ginger by micropropagation is an alternative to obtain a large number of seedlings 
in a short period of time and production of high quality, pathogen-free plants. The additional use of AMF inoculation technology during the acclimatization process can reduce mortality, reduce the use of fertilizers and increase seedling resistance to transplanting stress as well (Hooker et al., 1994). The aim of this study was to investigate the effect of AMF inoculation and $\mathrm{P}$ addition on growth of micropropagated ginger during the acclimatization phase.

\section{MATERIAL AND METHODS}

\section{Biological material}

To obtain micropropagated plantlets of $Z$. officinale, buds were cut from washed rhizomes and immersed in $3 \%$ sodium hypochloride for $20 \mathrm{~min}$, followed by immersion in $70 \%$ alcohol for 2 min. Buds were then soaked for $48 \mathrm{~h}$ in a solution containing $0.25 \mathrm{~g} \mathrm{~L}^{-1}$ of Manzate $800,1 \mathrm{~g} \mathrm{~L}^{-1}$ of Benlate 500 and $100 \mathrm{mg} \mathrm{L}^{-1}$ of Streptomicin Sulphate. After disinfection, buds were transferred to Murashige-Skoog (MS) medium, solidified with $7 \mathrm{~g} \mathrm{~L}^{-1}$ agar and supplemented with sacarose $\left(30 \mathrm{~g} \mathrm{~L}^{-1}\right)$ and $10 \mathrm{mmol} \mathrm{L}^{-1}$ of BAP (6- Benzylaminopurine). The $\mathrm{pH}$ of the medium was raised to 5.8 before autoclaving. Cultures were maintained at the following growth conditions: $27^{\circ} \mathrm{C}$; photoperiod of $16 \mathrm{~h}$, and light intensity of $50 \mu \mathrm{Em}^{2} \mathrm{~s}^{-1}$.

Mycorrhizal inoculum from each fungal isolate was obtained by multiplication of single cultures in pot cultures of Sorghum bicolor L. for three months and consisted of spores, hyphae and mycorrhizal root fragments. Pots containing sterilized substrate were also grown with $S$. bicolor to obtain non-mycorrhizal inoculum to be used on non-mycorrhizal treatments (Control and Phosphorus). Fungal isolates were obtained from the AMF culture collection of Universidade Regional de Blumenau and included: Glomus clarum Nicolson and Schenck (isolate RGS101A), Entrophospora colombiana Spain \& Schenck (isolate SCT115A), and Acaulospora koskei Blaszkowski (isolate SPL102A). Final spore density in the inoculum was 416, 23 and 20 spores $/ 50 \mathrm{~mL}$ soil for E. colombiana, A. koskei and G. clarum, respectively. Mycorrhizal and non-mycorrhizal inocula were homogenized with the substrate at a rate of $10 \%$.

Micropropagated ginger plantlets were separated in four homogenous groups of seven plants and transplanted into $180 \mathrm{~mL}$ plastic pots filled with $160 \mathrm{~mL}$ of a sterilized soil (Cambissolo) and river sand $\operatorname{mix}(1: 2, \mathrm{v} / \mathrm{v}, \mathrm{pH} 6.0)$. At transplanting, plantlets were subjected to the following treatments: nonmycorrhizal control without $\mathrm{P}$ addition (C), phosphorus (P), mycorrhizal inoculation (M), mycorrhizal + phosphorus (MP). Phosphorus (25 $\mathrm{mg} \mathrm{kg}^{-1}$ ) was added as $\mathrm{KH}_{2} \mathrm{PO}_{4}$, corresponding to the rate applied under field conditions to ginger plantations. Plantlets were acclimatized in a growth chamber at a temperature of $25^{\circ} \mathrm{C}$. After this period, they were grown in a greenhouse (16 h light), at a temperature between 20 and $25^{\circ} \mathrm{C}$, and supplemented with fluorescent light $\left(16.2 \mu \mathrm{Em}^{2} \mathrm{~s}^{-1}\right)$ up to three months. Plants plus substrate were then transferred to the center of $500 \mathrm{~mL}$ plastic pots (one plant per pot) and a sterile soil-sand mix was added to fill the pot. At this moment, each pot was supplemented with $50 \mathrm{~mL}$ of a commercial nutrient solution (Ouro Verde ${ }^{\circledR}$ - NPK 6-6-8\%) and left to grow for another five months until harvest. Plants were watered daily with tap water as needed. Treatments were arranged in a completely randomized design (CRD) with seven replications.

\section{Plant harvest}

At harvest, the total number of leaves and number of shoots per rhizome were recorded. The height of each shoot was recorded and averaged to estimate plant height. Shoots and rhizomes were placed on a convection oven $\left(48 \mathrm{~h}\right.$ at $60^{\circ} \mathrm{C}$ ) and their dry weights measured. Roots were removed from the soil, carefully washed and the excess of water removed using blottingpaper. Half of the root total fresh weight was used for mycorrhizal assessment and the other half was dried to obtain root dry weight. The equivalent amounts of root dry mass removed to determine mycorrhizal colonization were added to the mass measured for the remaining root fractions to calculate total root weights. The leaf area was measured for the first two leaves of each shoot using a planimeter.

\section{Mycorrhizal assessment}

Root samples were stained with $0.05 \%$ Trypan blue following the procedures described by Koske \& Gemma (1989) and the percentage of mycorrhizal root colonization was assessed using the grid line method of Giovannetti \& Mosse (1980). AMF spores were extracted from $50 \mathrm{~g}$ of soil from M and MP plants by wet sieving (Gerdemann \& Nicolson, 1963) following $20 / 60 \%$ sucrose gradient and counted under a dissecting microscope.

\section{Statistical analysis}

Homogeneity of variance of the data was tested using the Levene's test. A one-way ANOVA was carried out on the data and when the $\mathrm{F}$ test was significant, treatment means were separated using the post hoc Tukey's test. All statistical analyses were performed using the JMP statistical package.

\section{RESULTS}

At the end of the experiment, mycorrhizal root colonization and AMF sporulation were not detected for $\mathrm{C}$ and $\mathrm{P}$ plants. Values of mycorrhizal colonization of ginger roots were 81.4 and $92.9 \%$ in the $\mathrm{M}$ and $\mathrm{MP}$ 
treatments, respectively. Spore number of individual $\mathrm{AMF}$ isolates composing the inoculum was not affected by the addition of $25 \mathrm{mg} \mathrm{kg}^{-1}$ of $\mathrm{P}$ to the soil (Figure 1). Entrophospora colombiana SCT115A and Acaulospora koskei SPL102A were the most prolific sporulators at the end of the experiment, the former producing 697 and 521 spores/50 g soil and the latter producing 442 and 425 spores/50 g soil in the $\mathrm{M}$ and MP treatments, respectively.

The post vitro survival rate of ginger plants was $71 \%$ in $\mathrm{C}$ and $\mathrm{P}$ treatments, $86 \%$ in $\mathrm{M}$ treatments and $100 \%$ in MP treatments. Ginger shoot and root biomass were significantly increased by mycorrhizal inoculation and $\mathrm{P}$ addition compared to control (Table 1). Shoot biomass was slightly increased on M and MP plants but the effect was not significant

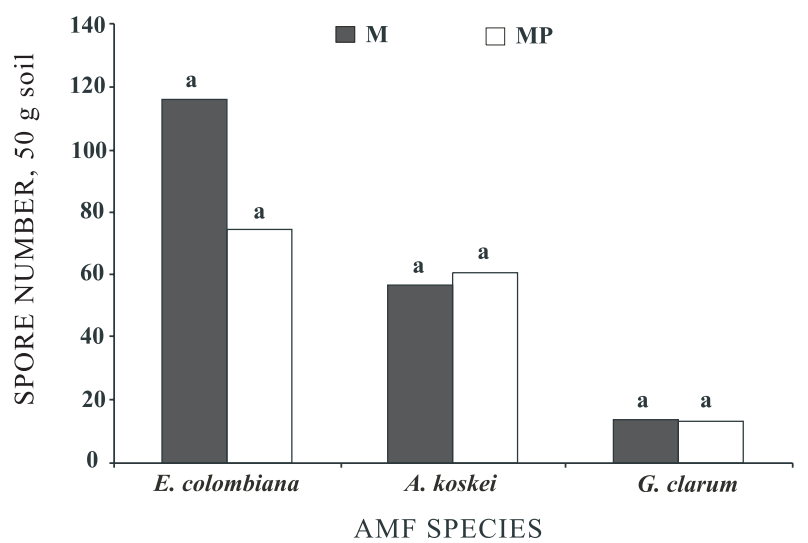

Figure 1. Number of spores (in $50 \mathrm{~g}$ of soil) of Entrophospora colombiana SCT115A, Acaulospora koskei SPL102A and Glomus clarum RGS101A composing the mycorrhizal mixture inoculated on micropropagated Zingiber officinale, after eight months. M: mycorrhizal treatment, MP: mycorrhizal + phosphorus treatment. Bars followed by the same letter for each AMF isolate are not significantly different (Tukey, $p<0.05$ ).

Table 1. Shoot, root and rhizome biomass of micropropagated ginger plants after five months under distinct mycorrhizal and phosphorus treatments

\begin{tabular}{cccc}
\hline Treatment & Shoot & Root & Rhizome \\
\hline & & $\mathrm{g}$ & \\
\cline { 2 - 4 } & & & \\
C & $0.17 \pm 0.07 \mathrm{~b}$ & $0.03 \pm 0.01 \mathrm{~b}$ & $0.06 \pm 0.08 \mathrm{~b}$ \\
M & $1.00 \pm 0.13 \mathrm{a}$ & $0.20 \pm 0.08 \mathrm{a}$ & $0.19 \pm 0.07 \mathrm{a}$ \\
$\mathrm{P}$ & $0.84 \pm 0.17 \mathrm{a}$ & $0.22 \pm 0.05 \mathrm{a}$ & $0.20 \pm 0.07 \mathrm{a}$ \\
MP & $0.95 \pm 0.13 \mathrm{a}$ & $0.20 \pm 0.09 \mathrm{a}$ & $0.20 \pm 0.02 \mathrm{a}$
\end{tabular}

C: control, M: mycorrhizal, P: phosphorus, MP: mycorrhizal + phosphorus. Mean followed by the same letter within each column are not statistically significant according to Tukey $(\mathrm{p}<0.05)$ compared to P plants. The opposite trend was observed for root biomass although significant differences were not observed between $\mathrm{M}$ and $\mathrm{MP}(0.20 \mathrm{~g})$ compared to $\mathrm{P}(0.22 \mathrm{~g})$. $\mathrm{M}$ and $\mathrm{P}$ plants produced 588 and $494 \%$ more shoot biomass and 666 and $733 \%$ more root biomass, respectively, compared to C plants. Rhizome dry biomass significantly increased threefold by mycorrhizal inoculation and phosphorus addition compared to $\mathrm{C}$ plants (Table 1 ).

The leaf numbers of micropropagated ginger plants grown in the $\mathrm{M}, \mathrm{P}$ and $\mathrm{MP}$ treatments were significantly higher than in C plants (Figure 2a). Leaf
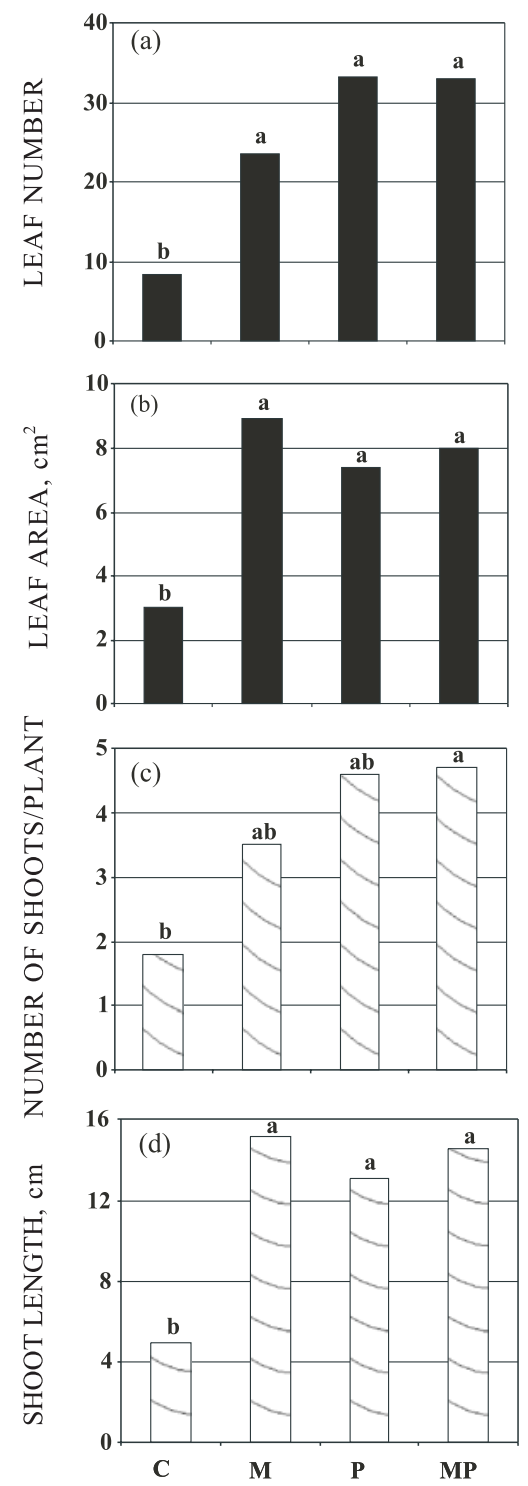

Figure 2. Leaf number (a), leaf area (b), number of shoot per plant (c), and shoot length (d) of micropropagated Zingiber officinale after eight months of growth. C: control, M: mycorrhizal, P: phosphorus, MP: mycorrhizal + phosphorus. Bars followed by the same letter within each variable are not significantly different (Tukey, $\mathrm{p}<0.05)$. 
area averaged $3 \mathrm{~cm}^{2}$ in $\mathrm{C}$ plants, which was significantly lower compared to other treatments where this variable ranged from 7.4 to $8.9 \mathrm{~cm}^{2}$ (Figure 2b). No significant differences were observed between the leaf area of plants in the M, P and MP treatments. The number of shoots produced per plant was statistically increased by the MP treatment while mycorrhizal inoculation $(\mathrm{M})$ and $\mathrm{P}$ addition $(\mathrm{P})$ alone caused no difference to control (C) plants (Figure 2c). Shoot length followed the same trend as observed for leaf area (Figure $2 \mathrm{~d}$ ).

\section{DISCUSSION}

This study provides clear evidence of the growth response of micropropagated ginger plants to mycorrhizal symbiosis. All growth variables measured were significantly increased with the inoculation of a mixture of AMF isolates, with the addition of $\mathrm{P}$ and with both mycorrhizal inoculation and $\mathrm{P}$ addition. Considering shoot biomass of the MP treatment relative to non-mycorrhizal C plants, which considers the growth attributed to mycorrhizae at a $\mathrm{P}$ level of $25 \mathrm{mg} \mathrm{kg}^{-1}$, the relative mycorrhizal dependency of ginger is $82 \%$, according to Plenchette et al. (1983). There are few reports on the interaction of AMF and $Z$. officinale in the literature, although the family Zingiberaceae has been surveyed for this association. Asai (1934) reported that Zingiber mioga Roscoe was endomycorrhizal. Taber \& Trappe (1982) first reported the occurrence of hyphae and vesicles of Glomus on the rhizomatous tissues, scale-like leaves and roots of Zingiber officinale samples from Fiji Island and Hawaii. Stasz \& Sakai (1984) reported AMF structures occurring on scale-like leaves of six genera of Zingiberaceae. Silva et al. (2006) found no influence of mycorrhizal inoculation on reducing the weaning (acclimatization) phase and increasing growth of micropropagated Zingiber spectabile Griff., a species closely related to ginger. This study is therefore the first to address the effect of mycorrhizal inoculation on ginger growth.

Several studies demonstrated the benefit of mycorrhizal inoculation on survival and establishment of micropropagated plants in the weaning phase. Fortunato et al. (2005) registered a survival percentage of micropropagated artichokes between 90 and $95 \%$ when inoculated with Glomus viscosum strain A6. Declerck et al. (2002) observed the largest growth increment of micropropagated banana plantlets with inoculation during the weaning phase. The present study confirms this pattern, since the survival of micropropagated ginger plants exceeded $80 \%$ in both AMF-inoculation treatments. In micropropagation systems, the weaning stage represents a development phase where plants are subjected to environmental stress due to poor root, shoot and cuticular development (Hooker et al., 1994) and our results represent direct evidence that $\mathrm{AMF}$ inoculation helps ginger microplants to overcome these stresses.

Inoculation of ginger plants with a mixture of AMF had the same effect on growth variables as a soil application of $25 \mathrm{mg} \mathrm{kg}^{-1}$ of $\mathrm{P}$, providing strong evidence that AMF inoculation in the weaning phase of micropropagated ginger represents a possibility of reducing fertilizer inputs in large-scale ginger production. A similar effect was observed for micropropagated strawberry where AMF inoculation during the post vitro stage increased berry yield and fruit mass of plants up to $150 \mathrm{~kg} \mathrm{ha}^{-1}$ of $\mathrm{P}$ (Sharma \& Adholeya, 2004). It is important to stress that not only shoot and root biomass were increased but also rhizome biomass, which contains both the aromatic and pungent components responsible for the strong aroma and use in foods and beverages (Sekiwa-Iijima et al., 2001). Some studies demonstrated the beneficial effect of AMF inoculation on growth of stem tissue (tubers). Vosátka \& Grindler (2000) observed that the beneficial effect of a dual AMF and bacteria inoculation on potato minituber production varied according to the host variety. Duffy \& Cassells (2000) showed that two commercial mycorrhizal inoculants increased the number of tubers suitable for potato seed under field conditions. Although no follow-up experiment in the field was carried out, the greenhouse experiment suggests that AMF inoculation may significantly increase ginger rhizome production.

One can speculate on the mechanism by which AMF increase rhizome biomass. Plant growth improvement of the mycorrhizal symbiosis is normally attributed to the increase of $\mathrm{P}$ uptake by the extraradical mycelium (Smith \& Read, 1997), leading to larger shoots and roots, compared to nonmycorrhizal plants. Indeed, in this study AMFinoculation significantly increased leaf number, leaf area and number of shoots per plant, which are all variables related to production of $\mathrm{C}$ compounds through photosynthesis that are translocated to underground rhizomes. On the other hand, the observation of hyphae and vesicles of Glomus colonizing the rhizome tissue of $Z$. officinale, an association denominated "mycorrhizome" by Taber \& Trappe (1982), might represent a new avenue for nutrient exchange between symbionts: AMF downloading $\mathrm{P}$ directly into a stem tissue and receiving (or not) $\mathrm{C}$ compounds from the rhizome. This scenario is not completely new as the primitive condition of this symbiosis in the fossil record demonstrates the association of an AMF-like structure with subterraneous rhizome tissue of the early vascular plant Aglaophyton major (Taylor et al., 1995). The exchange of photosynthates and $\mathrm{P}$ ions is proposed to occur through the intercellular mycelium growing on active roots (Smith \& Read, 1997) and there is no reason for this exchange process not to occur between AMF hyphae and stem tissues of ginger rhizomes. 


\section{CONCLUSION}

1. The methodology described in this study is suitable for the production of micropropagated Zingiber officinale Roscoe plantlets and further acclimatization under greenhouse conditions. Under post vitro conditions, it is possible to establish a functional mycorrhizal symbiosis between AMF and micropropagated ginger plants and this condition is of paramount importance for the survival and development of this plant species.

2. Inoculation with an AMF mixture did not only strongly influence shoot, root and rhizome biomass production of ginger but also reduced or even replaced the chemical fertilizer input in the growth stages. This study showed that ginger is a plant with a high mycorrhizal dependency based on shoot biomass production.

\section{ACKNOWLEDGEMENTS}

This study is part of a research project of the first author of the Program for Scientific Initiation. RS and CGG are in debted to the Program PIPe Art. 170 for research fellowships during the development of this project. This study was supported by a grant from Fundação de Amparo à Pesquisa Cientifica e Tecnológica do Estado de Santa Catarina (FAPESC). We would like to acknowledge Daiane Janaina de Souza for technical assistance with the experimental work.

\section{LITERATURE CITED}

ASAI, T. Über das vorkommen und die bedeutung der wurzelpilze in den landpflanzen. Japanese J. Bot., 7:107. 150,1934

BORKOWSKA, B. Growth and photosynthetic activity of micropropagated strawberry plants inoculated with endomycorrhizal fungi (AMF) and growing under drought stress. Acta Physiol. Plant., 24:365-370, 2002.

CAVALLAZZI, J.R.P.; KLAUBERG FILHO, O.; STÜRMER, S.L.; RYGIEWICZ, P.T. \& MENDONÇA, M.M. Screening and selecting arbuscular mycorrhizal fungi for inoculating micropropagated apple rootstocks in acid soils. Plant Cell Tissue Organ. Cult., 90:117-129, 2007.

DECLERCK, S.; RISEDE, J.-M. \& DELVAUX, B. Greenhouse response of micropropagated bananas inoculated with in vitro monxenically produced arbuscular mycorrhizal fungi. Sci. Hortic., 93:301-309, 2002.

DODD, J.C. The role of arbuscular mycorrhizal fungi in agroand natural ecosystems. Outlook Agric., 29:55-62, 2000.

DUFFY, E.M. \& CASSELLS, A.C. The effect of inoculation of potato (Solanum tuberosum L.) microplants with arbuscular mycorrhizal fungi on tuber yield and tuber size distribution. Applied Soil Ecol., 15:137-144, 2000.
EPAGRI. Normas técnicas para a cultura do gengibre - Litoral Catarinense e Litoral Paranaense. Florianópolis, Epagri/ Emater/IAPAR, 1998. 26p. (Sistema de Produção, 30)

FORTUNA, P.; CITERNESI, A.S.; MORINI, S.; VITAGLIANO, C. \& GIOVANNETTI, M. Influence of arbuscular mycorrhizae and phosphate fertilization on shoot apical growth of micropropagated apple and plum rootstocks. Tree Physiol., 16:757-763, 1996.

FORTUNATO, I.M.; RUTA, C.; CASTRIGNANÒ, A. \& SACCARDO, F. The effect of mycorrhizal symbiosis on the development of micropropagated artichokes. Sci. Hortic., 106:472-483, 2005.

GERDEMANN, J.W. \& NICOLSON, T.H. Spores of mycorrhizal Endogone species extracted from soil by wet sieving and decanting. Trans. British Mycol. Soc., 46:235244, 1963.

GIOVANNETTI, M. \& MOSSE, B. An evaluation of techniques to measure vesicular-arbuscular infection in roots. New Phytol., 84:489-500, 1980

GUILLEMIN, J.-P.; GIANINAZZI, S.; GIANINAZZIPEARSON, V. \& MARCHAL, J. Contribution of arbuscular mycorrhizas to biological protection of micropropagated pineapple (Ananas comosus (L.) Merr) against Phytophthora cinnamomi Rands. Agric. Sci. Finland, 3:241-252, 1994.

HOOKER, J.E.; GIANINAZZI, S.; VESTBERG, M.; BAREA, J.M. \& ATKINSON, D. The application of arbuscular mycorrhizal fungi to micropropagation systems: An opportunity to reduce chemical inputs. Agric. Sci. Finland, 3:227-232, 1994.

KOSKE, R.E. \& GEMMA, J.N. A modified procedure for staining roots to detect VA mycorrhizas. Mycol. Res., 2:488$505,1989$.

LOCATELLI, L.M.; LOVATO, P.E. \& PEDROTTI, E.L. Crescimento e desenvolvimento radicular do portaenxerto de macieira Marubakaido (Malus prunifolia) micropropagado submetido à inoculação micorrízica e à poda de raízes. R. Bras. Frutic., 24:486-490, 2002.

MONTICELLI, S.; PUPPI, G. \& DAMIANO, C. Effects of in vivo mycorrhization on micropropagated fruit tree rootstocks. Applied Soil Ecol., 15:105-111, 2000.

NEWSHAM, K.K.; FITTER, A.H. \& WATKINSON, A.R. Multifunctionality and biodiversity in arbuscular mycorrhizas. Trends Ecol. Evol., 10:407-411, 1995.

PLENCHETTE, C.; FORTIN, J.A. \& FURLAN, V. Growth response of several plants species to mycorrhizae in a soil of moderate phosphorus fertility. I. Mycorrhizal dependency under field conditions. Plant Soil, 70:158-161, 1983.

PURIN, S. \& RILLIG, M. The arbuscular mycorrhizal fungal protein glomalin: Limitations, progress, and a new hypothesis for its function. Pedobiologia, 51:123-130, 2007.

SEKIWA-IIJIMA, Y.; AIZAWA, Y. \& KUBOTA, K. Geraniol dehydrogenase activity related to aroma formation in ginger (Zingiber officianale Roscoe). J. Agric. Food Chem., 29:5902-5906, 2001 
SHARMA, M.P. \& ADHOLEYA, A. Effect of arbuscular mycorrhizal fungi and phosphorus fertilization on the post vitro growth and yield of micropropagated strawberry grown in a sandy loam soil. Canadian J. Bot., 82:322-328, 2004.

SCHELLENBAUM, L.; BERTA, G.; RAVOLANIRINA, F.; TISSERANT, B.; GIANINAZZI, S. \& FITTER, A.H. Influence of endomycorrhizal infection on root morphology in a micropropagated woody plant species (Vitis vinifera L.). Ann. Bot., 68:135-141, 1991.

SILVA, M.A.; SILVA, F.S.B.; YANO-MELO, A.M.; MELO, N.F. \& MAIA, L.C. Fungos micorrízicos arbusculares e vermicomposto na aclimatação de Alpinia purpurata (Viell.) Schum e Zingiber spectabile Griff. (Zingiberaceae). Acta Bot. Brasílica, 20:249-256, 2006.

SMITH, S.E. \& READ, D.J. Mycorrhizal symbiosis. London, Academic Press, 1997.
STASZ, T.E. \& SAKAI, W.S. Vesicular-arbuscular mycorrhizal fungi in scale-like leaves of Zingiberaceae. Mycologia, 76:754-757, 1984.

TABER, R.A. \& TRAPPE, J.M. Vesicular-arbuscular mycorrhizae in rhizomes, scale-like leaves, roots, and xylem of ginger. Mycologia, 74:156-161, 1982.

TAYLOR, T.N.; REMY, W.; HASS, H. \& KERP, H. Fossil arbuscular mycorrhizae from the Early Devonian. Mycologia, 87:560-573, 1995.

TAYLOR, J. \& HARRIER, L. A comparison of nine species of arbuscular mycorrhizal fungi on the development and nutrition of micropropagated Rubus idaeus L. cv. Glen Prosen (Red Raspberry). Plant Soil, 225:53-61, 2000.

VOsÁtKA, M. \& GRYNDLER, M. Response of micropropagated potatoes transplanted to peat media to post-vitro inoculation with arbuscular mycorrhizal fungi and soil bacteria. Applied Soil Ecol., 15:145-152, 2000. 